\title{
SPRAWOZDANIE PREZESA POLSKIEGO TOWARZYSTWA TEOLOGICZNEGO W KRAKOWIE ZA ROK 1997
}

\section{STAN TOWARZYSTWA}

1.1. Ostatnie Walne Zebranie Polskiego Towarzystwa Teologicznego w Krakowie, jakie odbyło się w dniu 18 lutego 1997 r., otwarło drugi rok kadencji obecnego zarządu Towarzystwa wybranego 14 lutego $1996 \mathrm{r}$. Ukonstytuowany wtenczas Zarząd Towarzystwa działal w roku sprawozdawczym w następującym składzie:

\subsubsection{ZARZĄD}

Prezes:

Wiceprezes:

Sekretarz:

Skarbnik:

Bibliotekarz: ks. dr hab. Kazimierz Panuś

o. dr Józef Marecki OFM Cap

ks. mgr Kazimierz Moskała

ks. mgr Andrzej Mojżeszko

ks. dr Jan Bednarczyk

ks. prof. dr hab. Stefan Koperek

\subsubsection{KOMISJA KONTROLUJĄCA:}

Przewodniczący: ks. dr Kazimierz Waliczek

Członkowie: ks. doc. dr hab. Jan Wal

ks. prałat Czesław Świniarski

\subsubsection{SAD KOLEŻEŃSKI:}

Przewodniczący: ks. inf. dr Stefan Cichy

Członkowie: ks. doc. dr hab. Jerzy Chmiel

o. dr hab. Jan Mazur OSPPE

1.2. Z końcem roku 1997 Polskie Towarzystwo Teologiczne w Krakowie liczyło - 463 członków. W roku sprawozdawczym przyjęto 71 nowych członków (w tym 66 do nowo powstałego Oddziału PTT w Częstochowie).

Do wieczności odszedł w ostatnich dniach ks. dr Marian Pawlos CM, kierownik Sekcji Misjologicznej.

\subsection{ZEBRANIA ZARZĄDU}

Spełniając wymogi statutowe Zarząd odbył w roku sprawozdawczym cztery zebrania w dniach:

16.04.1997 r., 18.06.1997 r., 19.11.1997 r., 17.02.1998 r. 
Pierwsze zebranie zdominowała problematyka nowo utworzonej sekcji PTT w Częstochowie; wysłuchano relacji kierownika tej sekcji ks. dra Teofila Siudego z zebrania organizacyjnego oraz przyjęto 38 pierwszych członków tego oddziału. Omówiono przygotowania do sympozjum Felix saeculum Cracoviae i powołano zespół badawczy heraldyki kościelnej i zakonnej przy Sekcji Historycznej PTT w Krakowie pod nazwą Studium Heraldyki Kościelnej.

Na drugim spotkaniu zarządu omówiono prace podejmowane przez oddział w Częstochowie; przyjęto 17 nowych członków. Zarząd podjął decyzję przygotowania do publikacji materiałów z sesji naukowej Krakowscy święci XV wieku.

Trzecie zebranie Zarządu poświęcone było przygotowaniu dzisiejszego Walnego Zebrania. Postanowiono poświęcić je upamiętnieniu idei, która zrodziła PTT i pierwszych lat działalności Towarzystwa. W związku z tym Zarząd zwrócil się z prośbą do ks. dra Józefa Wołczańskiego o przygotowanie i wygłoszenie wykładu na ten temat. W trakcie zebrania omówione zostały także plany powołania nowego oddziału PTT w Bielsku-Białej; wysłuchano informacji o sympozjum naukowym w Katowicach z okazji 50 -tej rocznicy śmierci ks. rektora Konstantego Michalskiego.

Zebranie czwarte odbyło się w dniu 17 lutego. Jego problematykę zdominowało omówienie Walnego Zebrania. Postanowiono uhonorować medalami i dyplomami Towarzystwa dwie osoby: ks. prof. dra hab. Tadeusza Wojciechowskiego oraz ks. prałata Rudolfa Broma. Zapoznano się $\mathrm{z}$ relacją na temat powolania nowego oddziału PTT Bielsku-Białej. Zarząd zwróci się do księży doktorów D. Oko i J. Olszewskiego z prośbą o podjęcie się zadania kierowników wakujących sekcji dogmatycznej i filozoficznej.

\section{DZIALALNOŚĆ TOWARZYSTWA}

2.1. W ramach PTT w Krakowie działa nominalnie 12 sekcji specjalistycznych i 7 oddziałów terenowych, przy czym sekcje filozoficzna i dogmatyczna faktycznie zawiesiły swoją działalność. PTT w Krakowie ma także własna Sekcję Wydawniczą w postaci wydawnictwa „Unum”.

2.1.1 SEKCJA BIBLIJNA. Przewodniczący - ks. prof. dr hab. Tomasz Jelonek. Sekcja w tym roku nie organizowała spotkań.

2.1.2 SEKCJA APOLOGETYCZNO-RELIGIOZNAWCZA. Kierownikiem sekcji jest ks. dr Tadeusz Dzidek. 9 grudnia ub. r. sekcja zorganizowała posiedzenie, w ramach którego ks. doc. dr hab. Łukasz Kamykowski przedstawil sprawozdanie z sympozjum watykańskiej Komisji TeologicznoHistorycznej Wielkiego Jubileuszu 2000 na temat: Korzenie antyjudaizmu $w$ kontekście chrześcijaństwa, a ks. dr Józef Morawa wygłosił referat nt. eklezjologii Waltera Kaspera.

2.1.3 SEKCJA HISTORYCZNA. Jej pracami kieruje ks. dr Andrzej Bruździński. W roku sprawozdawczym sekcja podejmowała szereg inicjatyw. Najpoważniejszą z nich była sesja naukowa Felix Saeculum Cracoviae - Krakowscy święci XV wieku zorganizowana 24 kwietnia 1997 wespół 
z Wydziałem Historii Kościoła PAT i Wyższym Seminarium Ojców Kapucynów w Krakowie. Sesja odbyła się pod patronatem honorowym J. Em. Ks. Kardynała Metropolity. Piętnastowieczną panoramę Krakowa, w którym żyło sześciu świątobliwych męźów (Jan Kanty, Szymon z Lipnicy, Stanisław Kazimierczyk, Izajasz Boner, Michał Giedroyć i Świętosław, zwany przez siebie samego "Milczacym») przedstawili znani profesorowie i wykładowcy J. Wyrozumski, W. Szelińska, ks. J. Związek, R. Zawadzki, o. W. Murawiec, ks. S. Ryłko, ks. A. Bruździński, o. P. Sczaniecki i W. Kolak. Sesję zaszczycił swoja obecnością ks. kard. F. Macharski, który otworzył obrady i wygłosił słowo wstępne, a na zakończenie przewodził uroczystej Eucharystii w kościele św. Marka. Materiały sesyjne ukażą się drukiem. Zarząd PTT zwrócił się z prośbą do Komitetu Badań Naukowych o dofinansowanie tej pozycji.

Warte odnotowania jest również spotkanie Sekcji Historycznej PTT, jakie miało miejsce w dniu 3 grudnia ub. r. Poświęcono je problematyce koncyliaryzmu. Swoimi poszukiwaniami na ten temat podzielił się z zebranymi ks. dr Grzegorz Ryś. Pod patronatem Sekcji Historycznej PTT odbywają się również spotkania zespołu badawczego Studium Heraldyki Kościelnej.

2.1.4. SEKCJA HOMILETYCZNA. Przewodniczącym sekcji jest ks. dr hab. Kazimierz Panuś. W roku sprawozdawczym sekcja homiletyczna spotkała się dwukrotnie:

- pierwszy raz w ramach II Forum Kultury Słowa (Kraków-Przegorzały 26-28.09.1997). Jedno z posiedzeń tego ogólnopolskiego sympozjum poświęcone było językowi księży. O. dr Wiesław Przyczyna wygłosił referat $E d u$ kacja językowa księży; w dyskusji zabierali głos także inni członkowie Sekcji;

- drugi raz w ramach Kongresu Ewangelizatorów Wędrownych w Seminarium Księży Zmartwychwstańców 9-10.10.1997.

2.1.5. SEKCJA TEOLOGII MORALNEJ. Sekcję prowadzi ks. dr Kazimierz Kaczmarczyk. Sekcja ta wraz z opiekunem specjalizacji teologii moralnej na Wydziale Teologicznym PAT - ks. prof. dr hab. Janem Kowalskim, zorganizowała spotkanie księży wykładowców teologii moralnej z Wydziału Teologicznego PAT i z Seminariów Duchownych współpracujących z Wydziałem Teologicznym PAT. Spotkanie odbyło się w dniu 8 stycznia $1998 \mathrm{r}$. i wzięło w nim udział 26 uczestników.

2.1.6. SEKCJA SOCJOLOGICZNO-PASTORALNA. Pracami sekcji kieruje ks. dr Stefan Dobrzanowski. Skupia ona 21 członków, głównie wykładowców socjologii religii, teologii pastoralnej i katolickiej nauki społecznej. Sekcja odbyła jedno posiedzenie w dniu 14 listopada 1997 r. na którym kierownik sekcji przedstawił stan aktualnych badań nad religijnością polskiego społeczeństwa. Referat programowy nt. Chrześcijański polityk $i$ jego świadectwo wiary wygłosił członek sekcji ks. mgr Jan Palusiński. W dyskusji omówiono odpowiedzialny udział katolików w polityce oraz potrzebę wszechstronnych badań nad wpływem sekt na młodzież. Temu ostatniemu problemowi ma być poświęcona tegoroczna jesienna sesja sekcji. 
2.1.7. SEKCJA LITURGICZNA. Sekcję prowadzi ks. dr Stanisław Szczepaniec. Sekcja w roku sprawozdawczym nie organizowała spotkań.

2.1.8. SEKCJA MISJOLOGICZNA. Po śmierci w ostatnich dniach ks. Dra Mariana Pawlosa CM sekcja nie ma kierownika. Nie przedstawiła też sprawozdania ze swej działalności.

2.1.9. SEKCJA PRAWA KANONICZNEGO. Kierownikiem sekcji jest ks. dr Józef Rapacz. Sekcja nie przedstawiła sprawozdania ze swej działalności.

2.1.10. SEKCJA SZTUKI SAKRALNEJ. Kierownikiem sekcji jest ks. dr Zdzisław Kliś. Staraniem sekcji - na jesieni ub. roku - ukazal się drukiem drugi tom Studia do dziejów kościoła św. Krzyża w Krakowie. Sekcja przygotowuje kolejną sesję na ten temat, która będzie miała miejsce pod koniec maja b.r.

2.1.11-12. SEKCJA DOGMATYCZNA I FILOZOFICZNA - praktycznie nie funkcjonowała $w$ roku sprawozdawczym, gdyż mimo usilnych zabiegów Zarządowi nie udało się znaleźć kierowników sekcji.

2.2. Polskie Towarzystwo Teologiczne w Krakowie działa także poprzez swoje oddziały terenowe. I tak:

2.2.1. ODDZIAE TERENOWY PTT W KATOWICACH. Pracami sekcji kieruje ks. dr Antoni Reginek. Sekcja PTT w Katowicach była w minionym roku sprawozdawczym współorganizatorem (w lączności z Górnośląskim Międzyuczelnianym Tow. Akademickim «Universitas») sympozjum naukowego z okazji 50-tej rocznicy śmierci ks. rektora Konstantego Michalskiego. Miało ono miejsce w Wyższym Śląskim Seminarium Duchownym dnia 5 listopada ub. r. Temat sympozjum został sformułowany następująco: Heroicznie myśleć $i$ heroicznie działać, czyli o myśli twórczej ks. Konstantego Michalskiego (1879-1947). W ramach trzech sesji wygłoszono dziewięć interesujących wykładów ukazujących postać ks. rektora Konstantego Michalskiego w świetle jego pism filozoficznych, etycznych i historycznoliterackich.

Oprócz tego Sekcja Polskiego Towarzystwa Teologicznego w Katowicach odbyła w minionym roku sprawozdawczym dwa zebrania połączone z wykładami i dyskusją. Podczas pierwszego spotkania, które miało miejsce dnia 24 października 1997, ks. dr Tadeusz Czakański wygłosił wykład nt. Symbole eucharystyczne w ikonografii wczesnochrześcijańskiej. Prelekcja była bogato zilustrowana przeźroczami. Kolejne zebranie sekcji katowickiej PTT miało miejsce 5 grudnia 1997. Wypełnił je referat ks. mgra lic. Kazimierza Wolnego nt. Zwiazek Ślazaków z tradycja naukowq $i$ kultowa Krakowa (Uniwersytet Jagielloński i kult św. Barbary).

Zebrania katowickiej Sekcji PTT odbywają się tradycyjnie w Wyższym Seminarium Duchownym w Katowicach, a obok członków katowickiego Oddziału PTT bierze w nich także udział zainteresowane grono studentów teologii.

2.2.2. ODDZIAL TERENOWY PTT W CZESTOCHOWIE została powołana do życia 18 lutego ub. r. Na zebraniu organizacyjnym 11 kwietnia na 
kierownika sekcji wybrany został ks. dr Teofil Siudy. Sekcja podjęła działalność z podziwu godnym rozmachem. Po nie całym roku od chwili założenia może już poszczycić się zorganizowaniem dwudniowego sympozjum chrystologicznego Jezus Chrystus - Jedyny Zbawiciel (17-18.10.1997) z wykładami księży profesorów Stanisława Włodarczyka, Antoniego Troniny, Dionizego Łukaszuka, Piotra Jaskóły, Stanisława Urbańskiego, Jerzego Borowca. Sekcja częstochowska podjęła różne inicjatywy jak np. zaduszki teologiczne - wieczór modlitw i wspomnień, czy uroczystość opłatkową; na swe zebrania zaprasza z wykładami znanych profesorów (ks. Stanisław Grzybek, p. Karol Klauza); popularyzuje myśl teologiczną wśród wiernych taki charakter miały wykłady otwarte oddziału częstochowskiego PTT przed pielgrzymką Jana Pawła II zatytułowane Otwarci na stowo Piotra (18-24.05) oraz wykład kierownika sekcji w wigilię uroczystości Niepokalanego Poczęcia NMP Duch Święty zstqpi na Ciebie... (Łk 1,38) - refleksja teologiczna o więzi Maryi z Duchem Świętym. W pracach oddziału częstochowskiego aktywnie uczestniczy J.E. ks. abp Stanisław Nowak.

2.2.3. ODDZIAL TERENOWY PTT W KALWARII ZEBRZYDOWSKIEJ. Sekcją kieruje o. dr Romuald Kośla. W roku sprawozdawczym sekcja odbyła sześć spotkań. Na szczególną uwagę zasługuje sesja naukowa poświęcona postaci bł. Jana $\mathrm{z}$ Dukli w ramach przygotowań do uroczystości kanonizacyjnych (22.02.1997), dwudniowe sympozjum (5-6.05.1997) na temat: Jan Pawel II - Papiez pielgrzym (zorganizowane w ramach przygotowań do pielgrzymki papieskiej przez PAT, Instytut Geografii Religii UJ oraz Sanktuarium w Kalwarii). Referaty wygłosili także dwaj członkowie Sekcji PTT w Kalwarii: o. dr Oktawian Jusiak (Młodzieńcze pielgrzymki Karola Wojtyly do Kalwarii Zebrzydowskiej a fenomen Sanktuarium Kalwaryjskiego) i o. dr Edmund Świerczek (Znaczenie Sanktuarium Kalwaryjskiego w wypowiedziach i tekstach Jana Pawka II). W Święto Niepodległości miała miejsce sesja naukowa (11.11.1997) na temat: Franciszkanizm $w$ perspektywie nowych zadan Kościola kończacego się drugiego tysiaclecia, $\mathrm{z}$ referatami o. dr hab. Bonawentury Smolki, (Tradycyjny wymiar franciszkańskiego stylu życia), o. dra Tadeusza Słotwińskiego, (Św. Franciszek czlowiek, który swoim życiem odnawia $i$ fascynuje) i o. dr hab. Zdzisława Kijasa, (Teologia franciszkańska, teologia prawostawna, spojrzenie ekumeniczne).

2.2.4. ODDZIA£ TERENOWY PTT W PRZEMYŚLU. Pracami sekcji kieruje ks. dr hab. Marian Wolicki. W roku sprawozdawczym Sekcja PTT w Przemyślu zorganizowała pięć spotkań z referatami ks. mgra Marka Pieńkowskiego (Wprowadzenie $w$ życie duchowe $w$ Seminarium Duchownym), ks. dra Mariana Rojka, (Wplyw teologów posoborowych na formacje intelektualnq kapłanów), ks. mgra Jana Niemca (Zaktad Wychowawczy Ojców Jezuitów w Bqkowicach pod Chyrowem (1886-1939), ks. dra Tadeusza Śliwy (Spór o precedencję wśród duchowieństwa katolickiego obrzqdku tacinskiego $i$ greckokatolickiego (XVII-XVIII w.). Szczególny charakter miała sesja wyjazdowa sekcji przemyskiej PTT (10.V.1997) w Dynowie u ks. dziekana dra Stanisława Janusza, wiceprezesa sekcji. W jej ramach ks. dr Tadeusz Śliwa wygłosił referat Sw. Wojciech - zycie $i$ działalność. 
W sesji tej oprócz księży profesorów wzięli udział także przedstawiciele miejscowej społeczności.

2.2.5. ODDZIAL TERENOWY PTT W TARNOWIE. Kierownikiem sekcji jest ks. dr Zbigniew Wolak. Sekcja nie przedstawila sprawozdania ze swej działalności.

2.2.6. ODDZIA£ TERENOWY PTT W TUCHOWIE. Kierownik sekcji o. dr Stanisław Bafia CSsR. Sekcja nie przedstawila sprawozdania ze swej działalności.

2.2.7. ODDZIA£ TERENOWY PTT W RZESZOWIE. Kierownik sekcji ks. dr Stanisław Nabywaniec. Sekcja ta znajduje się wciąż w stanie organizacji. Zarząd nie dysponuje danymi o jej działalności.

\section{UWAGI KOŃCOWE}

Sprawozdanie z działalności skarbnika oraz Sekcji Wydawniczej PTT w Krakowie zostanie złożone oddzielnie.

Podsumowując działalność Zarządu na przestrzeni ostatniego roku za poważny sukces należy uznać powstanie i dynamiczną działalność częstochowskiego oddziału PTT. Znacznie powiększyły się szeregi Towarzystwa (przybyło 71 nowych czlonków, nastąpił wzrost liczebny Towarzystwa o 18,1\%). Upowszechniła się wiedza o naszym Towarzystwie. Zostały nawiązane kontakty $\mathrm{z}$ American Biographical Institute, Présence du livre français oraz Stowarzyszeniem Organizacji Pozarzqdowych "Klon".

Natomiast na przestrzeni ostatniego roku nie udało się Zarządowi ożywić działalności niektórych sekcji. Organizowanie spotkań sekcyjnych nie zawsze spotykało się $\mathrm{z}$ szerokim odzewem, a posiedzenia te gromadziły niewiele osób. Chlubnym wyjątkiem - obok w/w działalności Sekcji PTT w Częstochowie - są prace Sekcji Historycznej i Homiletycznej. Sympozja organizowane przez te sekcje miały duże audytorium i stanowiły znaczące wydarzenie odnotowywane przez prasę. Dorobek tych sekcji ukaże się w osobnych publikacjach zbierających wygloszone wtedy referaty.

Zarząd pragnie wyrazić szczerą wdzięczność wszystkim aktywnym członkom Towarzystwa, którzy mimo wielorakich trudności czynią wszystko, aby działalność Towarzystwa była kontynuowana i służła dalszemu ubogaceniu polskiej myśli teologicznej.

Zarząd dziękuje gorąco J. Em. ks. kard. Franciszkowi Macharskiemu za stała troskę o rozwój naszego Towarzystwa. 